\title{
Bioaccumulation of Macro- and Microelements in Herbaceous Plants in the River Valley
}

\author{
Agnieszka Parzych ${ }^{1 *}$, Jerzy Jonczak ${ }^{2}$
}

\author{
1 Pomeranian University in Słupsk, Institute of Biology and Environmental Protection, Arciszewskiego 22b, \\ 76-200 Słupsk, Poland \\ 2 Warsaw University of Life Sciences, Department of Soil Environment Sciences, Nowoursynowska 159, \\ 02-776 Warsaw, Poland \\ * Corresponding author's e-mail: parzycha1@op.pl
}

\begin{abstract}
The research was done in the upper course of the Kamienna Creek which is the left-bank tributary of River Słupia situated in the northern part of Poland within Leśny Dwór Forest Inspectorate area. The aim of the study was the comparison of accumulation properties of herbaceous plants in spring niches in relation to macro- and microelements. The shoots of research plant species showed a good supply of macro- and micronutrients. The highest contents of nutrients were found in the shoots of Athyrium filix-femina (Ni), Caltha palustris (Mg, Ca, Sr), Cardamine amara $(\mathrm{K}, \mathrm{Zn}, \mathrm{Fe}, \mathrm{Al})$, Carex rostrata $(\mathrm{Mn})$ and Solanum dulcamara $(\mathrm{N}, \mathrm{P}, \mathrm{Cu})$, and the lowest in shoots of Ajuga reptans $(\mathrm{P}, \mathrm{Zn}, \mathrm{Mn})$, Cardamine amara $(\mathrm{N}, \mathrm{Cu})$ and Carex rostrata $(\mathrm{K}, \mathrm{Mg}, \mathrm{Ca}, \mathrm{Sr}, \mathrm{Ni}, \mathrm{Fe}, \mathrm{Al})$. Herbaceous plants accumulated from $1767.23 \mathrm{mmol}_{\mathrm{c}} \mathrm{kg}^{-1}$ (Carex rostrata) to $2739.87 \mathrm{mmol}_{\mathrm{c}} \mathrm{kg}^{-1}$ (Caltha palustris) of all the analyzed elements. Macronutrients dominated in all herbaceous plant species (>99\%), and microelements ranged from $0.33 \%$ in Solanum dulcamara to $0.67 \%$ in shoots Cardamine amara. The share of nitrogen was from $38.8 \%$ to $56.8 \%$ of this amount, phosphorus from $2.9 \%$ to $3.9 \%$, potassium from $28.5 \%$ to $40.6 \%$, magnesium from $4.8 \%$ to $7.6 \%$, and calcium from $4.6 \%$ to $16.4 \%$. A large share of iron (from 33.7\% Athyrium filix-femina to 39.5\% Caltha palustris), manganese (from 9.2\% Cardamine amara to $28.8 \%$ Carex rostrata) and aluminum (from $16.7 \%$ Carex rostrata to $40.8 \%$ Cardamine amara) in total measured components indicates excessive downloading them through plants. During the three years of research done in spring niches, it was found that some plant species take up nutrients in the quantities exceeding their physiological demand, which enables to use some of them for forming e.g. artificial wetlands, stopping many impurities and forming protective barriers.
\end{abstract}

Keywords: riparian forest, peatbogs, herbaceous plants, nutrients, accumulation

\section{INTRODUCTION}

The effectiveness of nutrient uptake by plants is largely determined by the factors dependent on them, such as species, age, developmental phase, availability of components in soil and ionic interactions of synergistic and antagonistic nature [Ostrowska and Porębska 2002, Veselkin, et al. 2014]. The amount of components taken up is conditioned by the physiological demand for macro- and micronutrients [Kabata-Pendias and Pendias 1999], but it can also occur in the passive way due to the environmental pollution [Parzych 2016]. The nutrients taken up are used to build tissues and participate in many metabolic transformations. Seasonal variability of the environment and varied requirements of plants during the growing season determine the dynamic nature of the plant-environment relationship, especially in headwater ecosystems, where underground waters flowing to the surface create specific conditions for the development of soils [Karlsson et al. 2005, Jonczak and Parzych 2016, Jonczak et al. 2016] and plants [Parzych and Jonczak 2018]. A permanent excess of water creates favourable conditions for the accumulation of organic matter and development of dome-shaped bogs, typical for the headwater areas. Paludification of the area is conducive to the development of the rich diversity of 
plant species [Décamps et al. 2004, Osadowski 2006, Pielech et al. 2015]. The studies carried out so far indicate that some species of plants occurring within the mid-forest headwater niches have a high capacity for accumulation of macro- and micronutrients [Maine et al. 2006, Hazlett et al. 2008, Parzych et al. 2017, Parzych and Jonczak 2018]. The retention of nutrients in shoots of herbaceous plants is one of the most important processes occurring in river valleys, which act as buffer zones [Tufekcioglu et al. 2003, Hefting et al. 2005, Raty et al. 2010]. Species diversity and accumulation properties of herbaceous plants are the subject of numerous studies due to the significant impact of vegetation on the physicochemical properties of waters [Małek et al. 2010, Parzych et al. 2016, 2017]. The comparison of accumulation properties involving selected plant species in relation to macro- and microelements in the areas unaffected by anthropogenic factors, will allow to broaden the current knowledge about the possibility of using some of them, e.g. in water treatment processes [Viers et al. 2012, Parzych 2016].

The aim of the work was to compare the accumulation properties of Ajuga reptans, Athyrium filix-femina, Caltha palustris, Cardamine amara, Carex rostata and Solanum dulcamara growing over dome bogs in the mid-forest headwater niches in the river valley, in relation to macro- and micronutrients.

\section{MATERIAL AND METHODS}

\section{Stand characteristic}

The research was carried out in northern Poland, in the forest inspectorate of Leśny Dwór $\left(54^{\circ} 19^{\prime} \mathrm{N}, 17^{\circ} 10^{\prime} \mathrm{E}\right)$, in the upper course of the Kamienna Creek, left-bank tributary of the Slupia River (Fig. 1). The headwater niche chosen for research is located in a hilly upland cut with numerous streams, developed from boulder clays and fluvioglacial sands. The area of the Kamienna Creek basin is covered by forests characterized by spatially diversified species composition, with the dominance of beech, pine and spruce within upland and black alder in the valley bottom (Parzych et al. 2017]. Sampling points were located in the riparian headwater forest with the black alder stand (Alnus glutinosa). The forest stand overgrows bogs cut with headwater streams, built of alder peat with interbedings of alder-sedge peat [Jonczak et al. 2015a].

\section{Soil and plant sampling}

In the headwater riparian forest, there were two research sites located in the central part of the selected dome peat bogs. The soil samples were collected from the following layers: $0-10,10-20$ and 20-30 $\mathrm{cm}$, due to the largest cluster of roots. Within each site, representative species of herbaceous plants, characterized by the highest frequency and density, were selected: Ajuga reptans L. (Aju_rep), Athyrium filix-femina L. Roth (Ath_fil), Caltha palustris L. (Cal_pal), Cardamine amara L. (Car_ama) from site 1 and Carex rostata Stokes (Car_ros) and Solanum dulcamara L. (Sol_dul) from site 2 (Table 1). The nomenclature of plants growing on bogs was given according to Mirek et al. [2002]. The plant samples were collected for testing in May, July and September in 2012-2014. A single sample consisted of aerial shoots originating from a dozen or so specimens of a given species. In total, 54 plant samples were collected for the study.

\section{Soil and plant analysis}

After being transported to the laboratory, the soil samples were dried at $65^{\circ} \mathrm{C}$, and milled into powder. The plants were rinsed in distilled water to remove residual soil, then dried at $65^{\circ} \mathrm{C}$ and homogenised in a laboratory mill (IKA A11). Prior to the analyses, the samples were stored in tightly sealed polyethylene bags. Both in soil and plant samples, nitrogen was determined using the Kiejdahl method (Büchi K-350), and phosphorus with spectrophotometric method involving ammonium molybdate (UV-VIS, Hitachi U-5100) after digestion of samples in a mixture of $98 \% \mathrm{H}_{2} \mathrm{SO}_{4}$ and $30 \% \mathrm{H}_{2} \mathrm{O}_{2}$. For the determination of $\mathrm{K}, \mathrm{Mg}, \mathrm{Ca}, \mathrm{Zn}, \mathrm{Cu}, \mathrm{Ni}, \mathrm{Mn}, \mathrm{Fe}, \mathrm{Al}$ and $\mathrm{Sr}$, the samples were digested in a mixture of $65 \%$ $\mathrm{HNO}_{3}$ and $30 \% \mathrm{H}_{2} \mathrm{O}_{2}$ and then deionized water (Hydrolab HLP10) was added to the volume of $50 \mathrm{ml}$. The contents of $\mathrm{K}, \mathrm{Mg}, \mathrm{Ca}, \mathrm{Zn}, \mathrm{Cu}, \mathrm{Ni}, \mathrm{Mn}$ and $\mathrm{Fe}$ were determined with atomic absorption spectrometry using the Aanalyst 300 apparatus (Perkin Elmer), and $\mathrm{Al}$ and $\mathrm{Sr}$ by means of microwave plasma atomic emission spectrometry (Agilent 4100, MPAES). The apparatus was calibrated based on Merck standard solutions $(1 \mathrm{~g} / 1000 \mathrm{~mL})$. All analyzes were performed in triplicate.

\section{Data analysis}

The distribution of data on the physicochemical properties of soils and the chemical composition of plants was tested using Shapiro Wilk test. 

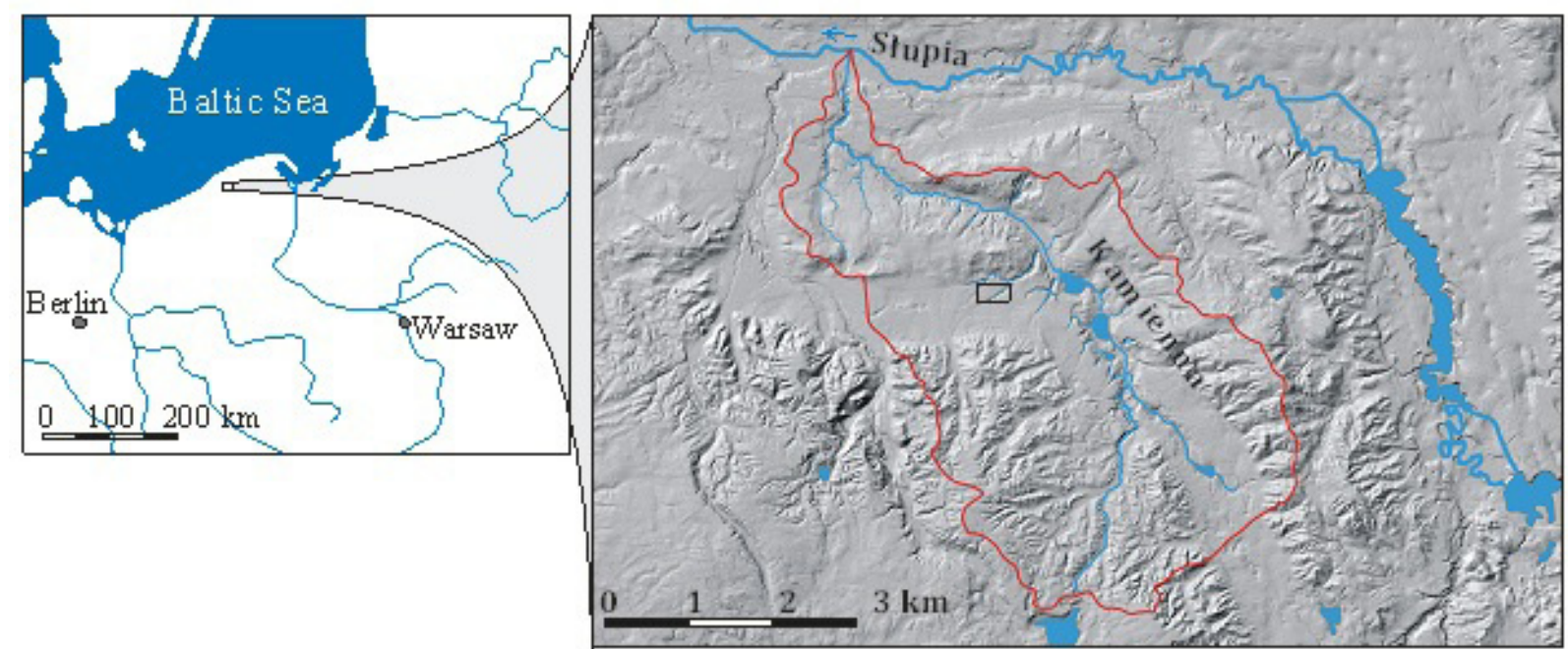

Figure 1. Hydrographic network, the boundaries of the catchment area of the Kamienna river and research area on the background of airborne LIDAR based Digital Elevation Model (DEM)

The results were presented in tables and figures, compared using non-parametric U Mann Whitney and Kruskal-Wallis tests. Statistica 7.1 software was used to develop the results. The demand of the studied plant species for nutrients was described using the ANE method (Accumulation Nutrient Elements), [Ostrowska and Porębska 2002]. The sum of components (Y) in mmol $\mathrm{kg}^{-1}$ was calculated based on a formula:

$$
\mathrm{Y}=\Sigma(\mathrm{Z}: \mathrm{z})
$$

where: $Z$ - content of the element in $\mathrm{mg} \cdot \mathrm{kg}^{-1}$

$z$ - atomic weight/ion valency

After the calculation of Y, the percentage (X) of each element in the sum of:

$$
\mathrm{X}=[(\mathrm{Z}: \mathrm{z}) \cdot 100] \cdot \mathrm{Y}^{-1}
$$

was calculated.

The studied plant species were grouped due to the similarity in the percentage of macro- and microelements in the sum of the accumulated components by means of the cluster method (Ward method).

\section{RESULTS AND DISCUSSION}

\section{Physicochemical properties of soil}

Due to the statistically insignificant differences in the physicochemical properties of soil samples between 0-10, 10-20 and 20-30 cm layers - in the further part of the work, reference is made to the mean values for the $0-30 \mathrm{~cm}$ layer. Within the studied headwater niche, there were peat soils with diversified thickness, not exceeding $1 \mathrm{~m}$. The content of organic matter remained on average at $21.9 \%$ (site 1 ) and $32.2 \%$ (site 2) (Table 1) it and slightly changed with depth. These soils were characterized by weakly acidic $\mathrm{pH}$, relatively poor nitrogen, potassium and magnesium content and on average, rich in phosphorus and calcium. The content of micronutrients in the analyzed soil layers was low and characteristic for peat soils not burdened with the influence of anthropogenic factors [Jonczak et al. 2014]. The solubility of most chemical compounds is small in terms of neutral and alkaline reactions [Smal and Salomons 1995], and increases with the lowering of the $\mathrm{pH}$ values [Gworek 2006]. Nitrogen compounds show the highest bioavailability at $\mathrm{pH}$ 6.0-8.0, phosphorus at $\mathrm{pH}$ 6.5-8.0, potassium at $\mathrm{pH} 6.0-10.0$, and calcium, magnesium and strontium at $\mathrm{pH} 6.5-8.5$. The increase in zinc mobility occurs most effectively at $\mathrm{pH} 6.0$, manganese at $\mathrm{pH} 6.0$ and 8.0, copper and nickel at $\mathrm{pH} 5.5$, iron at $\mathrm{pH} 4.0$, and aluminum at $\mathrm{pH} 5.5$ and below [Kabata-Pendias and Pendias 1999].

Statistically significant differences in active acidity $\left(\mathrm{pH}, \mathrm{H}_{2} \mathrm{O}\right)$ and in the concentration of potassium in the soil in the $0-30 \mathrm{~cm}$ layer between the sites were shown (Table 1). The soils in the studied headwater niche exhibited a number of specific features, resulting from their functioning in the spring water area, as a transition zone between the underground and surface part of the water cycle in river basins [Jonczak 2011]. Permanent flow of groundwater above the mineral substrate towards the river occurs in these soils, resulting in characteristic vertical gradients of 
Table 1. Physicochemical properties of soils (mean \pm SD) in $0-30 \mathrm{~cm}$ layer in the river valley with results of $U$ Mann Whitney test

\begin{tabular}{|c|c|c|c|c|}
\hline \multicolumn{2}{|c|}{ Parameter } & Location 1 & Location 2 & U Mann Whitney test $(p<0.05)$ \\
\hline \multicolumn{2}{|c|}{$\mathrm{OM}, \%$} & $21.9 \pm 1,5$ & $32.3 \pm 11.0$ & - \\
\hline \multicolumn{2}{|c|}{$\mathrm{pH}\left(\mathrm{H}_{2} \mathrm{O}\right)$} & ${ }^{*} 6.1 \pm 0.1$ & $\star 5.7 \pm 0.2$ & 0.049 \\
\hline \multicolumn{2}{|c|}{$\mathrm{pH}(\mathrm{KCl})$} & ${ }^{*} 5.4 \pm 0.1$ & ${ }^{*} 5.3 \pm 0.1$ & - \\
\hline $\mathrm{N}$ & \multirow{12}{*}{ 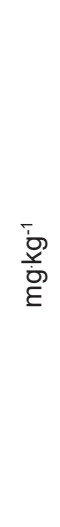 } & $9143.1 \pm 822$ & $11021.0 \pm 4072$ & - \\
\hline $\mathrm{P}$ & & $6947.2 \pm 1033$ & $6283.6 \pm 2326$ & - \\
\hline K & & $663.1 \pm 10$ & $1785.9 \pm 806$ & 0.049 \\
\hline $\mathrm{Mg}$ & & $898.4 \pm 19$ & $2082.9 \pm 1086$ & - \\
\hline $\mathrm{Ca}$ & & $7641.3 \pm 409$ & $10524.7 \pm 3996$ & - \\
\hline $\mathrm{Sr}$ & & $44.5 \pm 2$ & $57.8 \pm 24$ & - \\
\hline $\mathrm{Zn}$ & & $40.7 \pm 8$ & $62,0 \pm 26$ & - \\
\hline $\mathrm{Cu}$ & & $7.3 \pm 0.9$ & $10.8 \pm 4.6$ & - \\
\hline $\mathrm{Ni}$ & & $6.7 \pm 0.7$ & $9.4 \pm 4.8$ & - \\
\hline $\mathrm{Fe}$ & & $6221.5 \pm 629$ & $13198.9 \pm 6859$ & - \\
\hline $\mathrm{Mn}$ & & $244.2 \pm 65$ & $348.2 \pm 149$ & - \\
\hline $\mathrm{Al}$ & & $4928.9 \pm 209$ & $7901.9 \pm 4216$ & - \\
\hline
\end{tabular}

* - median, $\mathrm{p}$ - significance level, - no significant differences

concentrations of various components [Jonczak et al. 2015a]. The macro and micronutrients released in the processes of organic matter decomposition [Jonczak et al. 2015b] were easily washed away by the flowing spring waters beyond the reach of the plant root system [Parzych et al. 2017].

\section{Macro- and microelements concentrations in plants}

The content of macro- and microelements in the studied plants varied depending on the species. The highest concentrations of nitrogen and phosphorus were found in the shoots of Solanum dulcamara (20 $830 \mathrm{mgkg}^{-1}$ and $3483 \mathrm{mgkg}^{-1} \mathrm{re}-$ spectively), and the lowest in the case of Cardamine amara (14 $\left.030 \mathrm{mgkg}^{-1}\right)$ and Ajuga reptans (2 $019 \mathrm{mg} \mathrm{kg}^{-1}$ ), respectively (Fig. 2). According to Ostrowska and Porębska [2002], the natural content of nitrogen in green parts of plants is usually in the range from 13000 to $31000 \mathrm{mg} \mathrm{kg}^{-1}$ and phosphorus from 1000 to $4000 \mathrm{mg} \mathrm{kg}^{-1}$. In riparian forests, vegetation usually shows a good supply of biogens due to the high level of water table and easier access to many nutrients, in comparison to other forest ecosystem [Jansson et al. 2007, Kuglerová et al. 2014]. According to Krzywy [2007] the strong humidity of the soil, characteristic of spring areas, has a positive effect on the uptake of phosphorus by plants.

The highest concentration of potassium was demonstrated in the shoots of Cardamine amara (41 $123 \mathrm{mgkg}^{-1}$ ), and the lowest in the case of
Carex rostrata (19 $648 \mathrm{mg}^{-1} \mathrm{~kg}^{-1}$ ), (Fig. 1). For all species concerned, the results obtained exceeded the natural $\mathrm{K}$ content in plants $(2000-18000$ $\mathrm{mg} \cdot \mathrm{kg}^{-1}$ ) [Ostrowska and Porębska 2002]. Potassium is often absorbed by plants in excess [Krzywy 2007], especially in the forest ecosystems with a high level of groundwater table [Parzych et al. 2017]. High K content in the shoots of various plant species found in heavily moistened areas has been confirmed in the literature [SameckaCymerman and Kempers 2007, Horska-Schwarz and Spałek 2008, Parzych et al. 2017].

The most biogen-rich species was Caltha palustris, which accumulated the highest amounts of $\mathrm{Mg}\left(5016 \mathrm{mg} \cdot \mathrm{kg}^{-1}\right), \mathrm{Ca}\left(17197 \mathrm{mg} \cdot \mathrm{kg}^{-1}\right)$ and $\mathrm{Sr}$ (152.3 mgkg ${ }^{-1}$ ), (Fig. 2, 3). Simultaneously, Mg (2017 $\left.\mathrm{mgkg}^{-1}\right), \mathrm{Ca}\left(4247 \mathrm{mgkg}^{-1}\right)$ and $\mathrm{Sr}(35.9$ $\mathrm{mg} \cdot \mathrm{kg}^{-1}$ ) were found in the shoots (Fig. 2, 3). According to Ostrowska and Porębska [2002] the optimal content of magnesium and calcium in the shoots of most plant species is in the range: $1000-3000 \mathrm{mg}^{-1} \mathrm{~kg}^{-1}(\mathrm{Mg})$ and $1000-33000 \mathrm{mg}^{-1}$ (Ca). Comparable $\mathrm{Mg}$ contents (2000 $\mathrm{mg} \cdot \mathrm{kg}^{-1}$ ) and significantly lower $\mathrm{Ca}$ concentrations (2500 $\mathrm{mg} \mathrm{kg}^{-1}$ ) in surface shoots of Carex rostrata were shown by Czerwiński and Pracz [1995].

The shoots of the analyzed plants showed a good supply of micronutrients. Among the species studied, the highest amounts of $\mathrm{Ni}$ were found in Athyrium filix-femina, $\mathrm{Zn}, \mathrm{Fe}$ and $\mathrm{Al}$ in Cardamine amara, $\mathrm{Mn}$ in Carex rostrata, and $\mathrm{Cu}$ in Solanum dulcamara. The smallest concentrations of $\mathrm{Zn}, \mathrm{Mn}$ occurred in the shoots of Ajuga 
reptans, $\mathrm{Cu}$ in Cardamine amara, and $\mathrm{Sr}, \mathrm{Ni}, \mathrm{Fe}$ and $\mathrm{Al}$ in Carex rostrata. All of the analyzed species showed increased concentrations of nickel $(>10 \mathrm{mg} / \mathrm{kg}$ ) [Kabata-Pendias and Pendias 1999], (Fig. 3). The main source of nickel in the studied headwater riparian forest is organic precipitation and soil. The research results obtained by Jonczak et al. [2014] and Jonczak and Parzych [2014] indicate that the main fraction of organic fall (alder leaves) contains much higher Ni concentrations than soil. This element is released very quickly during the mineralization processes and supplies spring waters, from where it is taken up by plants [Jonczak et al. 2015b]. The Kruskal-Wallis test showed statistically significant differences in the concentration of $\mathrm{Ca}$ and $\mathrm{Sr}$ at $\mathrm{p}<0.001, \mathrm{~K}$ and $\mathrm{Mg}$ at $\mathrm{p}<0.01$ as well as $\mathrm{P}, \mathrm{Mn}$ and $\mathrm{Al}$ at $\mathrm{p}<0.05$ between the tested plant species (Fig. 2, 3).

The amount of nutrients taken in by plants depends to a large extent on the demand for individual components and on soil properties [KabataPendias and Pendias 1999], (Tab. 1). The reaction of soils in the studied niche promoted the uptake of macronutrients and limited the availability of some micronutrients for plants.
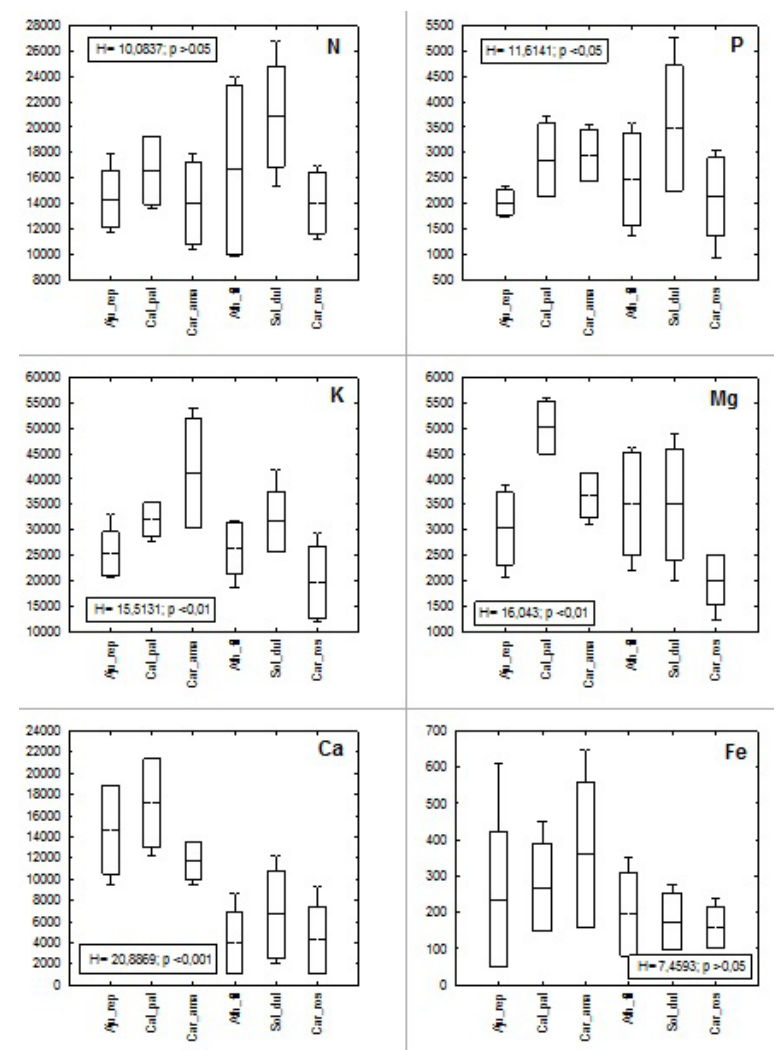

Figure 2. Average contents $\left(\mathrm{mg}_{\mathrm{kg}}{ }^{-1}\right) \mathrm{N}, \mathrm{P}, \mathrm{K}, \mathrm{Mg}, \mathrm{Ca}$ and $\mathrm{Fe}$ in shoots of herbaceous plants with the results of Kruskal-Wallis test. Rectangle - standard deviation, mustache - min-max

\section{Macro- and microelements accumulation in plants}

On the basis of the concentration of elements in plants, the sum of macro- and microelements was calculated using the ANE method (Accumulation Nutrient Elements), according to Ostrows$\mathrm{ka}$ and Porębska [2002]. The sum of ingredients reflects the so-called nutritional factor. The value of the sum of ingredients and its ionic composition determine the flow of nutrients between the soil and the plant. The percentage share of individual components in their sum depends on the nutritional requirements of plants in relation to the analyzed nutrients [Parzych and Cymer 2014].

The shoots of herbaceous plants of the headwater niche tested accumulated from 1767.23 mmol $\mathrm{kg}^{-1}$ (Carex rostrata) to $2739.87 \mathrm{mmol}_{\mathrm{c}} \mathrm{kg}^{-1}$ (Caltha palustris) of all analyzed components (Table 2). Macronutrients, the share of which was over $99 \%$, were dominant in all analyzed species, and micronutrients constituted from $0.33 \%$ in $\mathrm{So}$ lanum dulcamara to $0.67 \%$ in Cardamine amara shoots. The ionic composition of the sum of macroelements in the shoots of the headwater plants
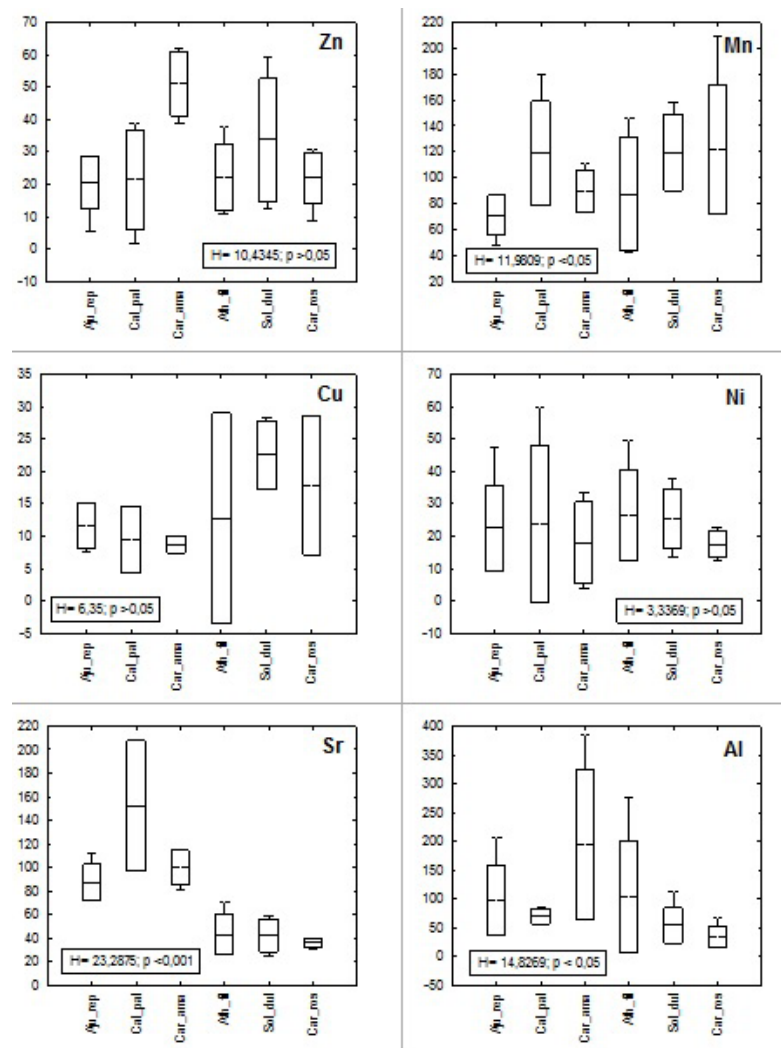

Figure 3. Average contents $\left(\mathrm{mg} \cdot \mathrm{kg}^{-1}\right) \mathrm{Mn}, \mathrm{Cu}, \mathrm{Ni}, \mathrm{Zn}$, $\mathrm{Sr}$ and $\mathrm{Al}$ in shoots of herbaceous plants with results of Kruskal-Wallis test. Rectangle - standard deviation, mustache - min-max 
Table 2. Average accumulation of macro- and microelements in shoots of plants in the river valley

\begin{tabular}{|c|c|c|c|}
\hline Species & $\Sigma$ macro, $\mathrm{mmol}_{\mathrm{c}} \cdot \mathrm{kg}^{-1}$ & $\begin{array}{c}\sum \text { micro, } \mathrm{mmol}_{\mathrm{c}} \mathrm{kg}^{-1} \\
(\text { participation \%) }\end{array}$ & $\Sigma$ macro $+\Sigma$ micro $\mathrm{mmol}_{\mathrm{c}} \cdot \mathrm{kg}^{-1}$ \\
\hline Ajuga reptans & 2230.62 & $11.00(0.49)$ & 2241.61 \\
\hline Athyrium filix-femina & 2191.52 & $10.41(0.49)$ & 2201.92 \\
\hline Calha palustris & 2739.87 & $12.20(0.44)$ & 2752.07 \\
\hline Cardamine amara & 2597.65 & $17.61(0.67)$ & 2615.26 \\
\hline Carex rostrata & 1767.23 & $7.67(0.43)$ & 1774.90 \\
\hline Solanum dulcamara & 2724.10 & $9.09(0.33)$ & 2733.20 \\
\hline Range & $1767.23-2739.87$ & $7.67-17.61$ & $1774.90-2733.20$ \\
\hline
\end{tabular}

was significantly different, depending on the species, compared to plants growing on the soils with much moisture content [Ostrowska and Porębska 2002, Parzych 2015].

The obtained sums of macro- and micronutrients for plants in the studied spring niche were comparable for the majority of species growing in the riparian forests [Parzych et al. 2018] and much higher than in the case of other species found in river valleys [Parzych et al. 2015]. The share of nitrogen constituted from 38.8\% (Cardamine amara) to $56.8 \%$ (Carex rostrata) of this sum, phosphorus from $2.9 \%$ (Ajuga reptans) to $3.9 \%$ (Carex rostrata), potassium from $28.5 \%$ (Carex rostrata) to $40.6 \%$ (Cardamine ama$r a$ ), magnesium from $4.8 \%$ (Carex rostrata) to 7.6\% (Caltha palustris), and calcium from $4.6 \%$ (Athyrium filix-femina) to $16.4 \%$ (Ajuga reptans), (Fig. 4). The high proportion of iron (from $33.7 \%$ Athyrium filix-femina to $39.5 \%$ Caltha palustris), manganese (from 9.2\% Cardamine amara to $28.8 \%$ Carex rostrata) and aluminum (from $16.7 \%$ Carex rostrata to $40.8 \%$ Cardamine amara) in the total of the measured components (Fig. 5) indicates their excessive absorp- tion by plants from soil, which was favoured by a slightly acidic reaction (Table 1).

Among the species examined, similarities were observed regarding the percentage of macro- and microelements in the shoots of herbaceous plants (Fig. 6). Both Solanum dulcamara and Carex rostrata were characterized by a very similar percentage of all tested components. Cardamine amara and Athyrium filix-femina exhibited a similar proportion of $\mathrm{P}, \mathrm{Mg}$ and $\mathrm{Zn}$, and Caltha palustris and Ajuga reptans of K, Ca, Zn, Ni and $\mathrm{Fe}$ in total amount of the analyzed nutrients.

\section{CONCLUSION}

The herbaceous plants in the studied headwater niche showed a good supply of both macro and micronutrients. The highest amounts of nutrients were found in the shoots of: Athyrium filix-femina $(\mathrm{Ni})$, Caltha palustris $(\mathrm{Mg}, \mathrm{Ca}, \mathrm{Sr})$, Cardamine amara (K, Zn, Fe, Al), Carex rostrata $(\mathrm{Mn})$ and Solanum dulcamara $(\mathrm{N}, \mathrm{P}, \mathrm{Cu})$. The lowest concentrations of the nutrients were found in the shoots of Ajuga reptans (P, Zn, Mn),

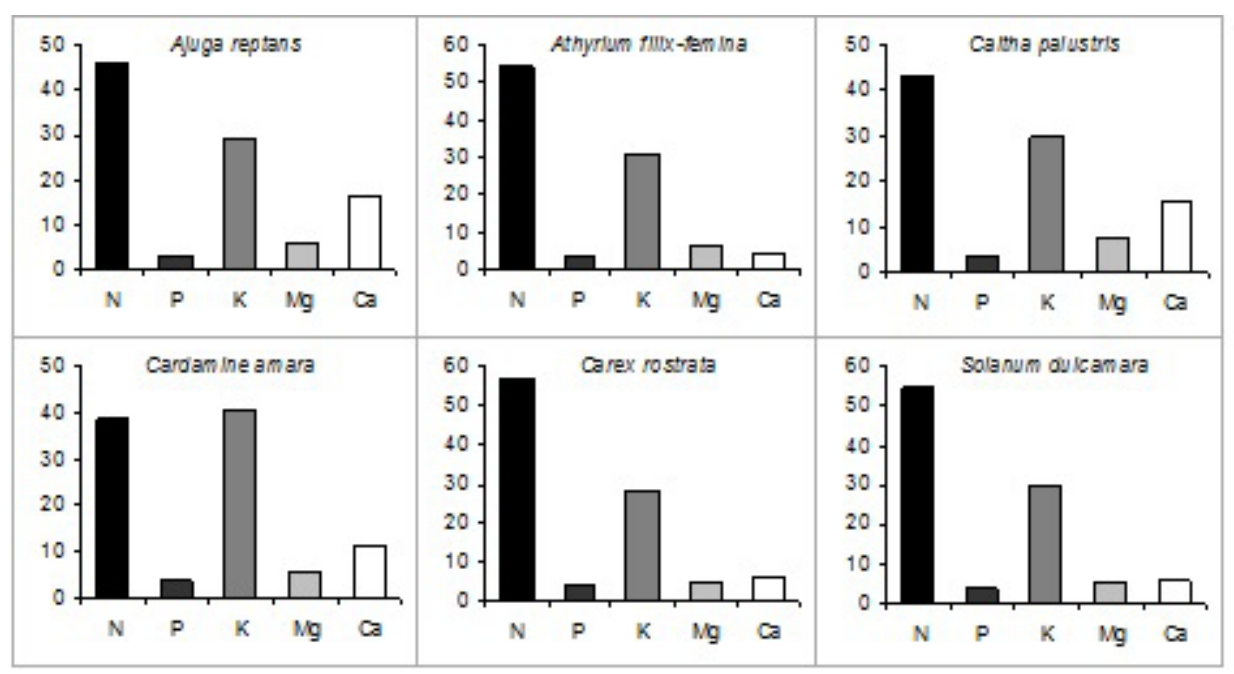

Figure 4. Percentage share of $\mathrm{N}, \mathrm{P}, \mathrm{K}, \mathrm{Mg}$ and $\mathrm{Ca}$ in amount macronutrients in herbaceous plants 

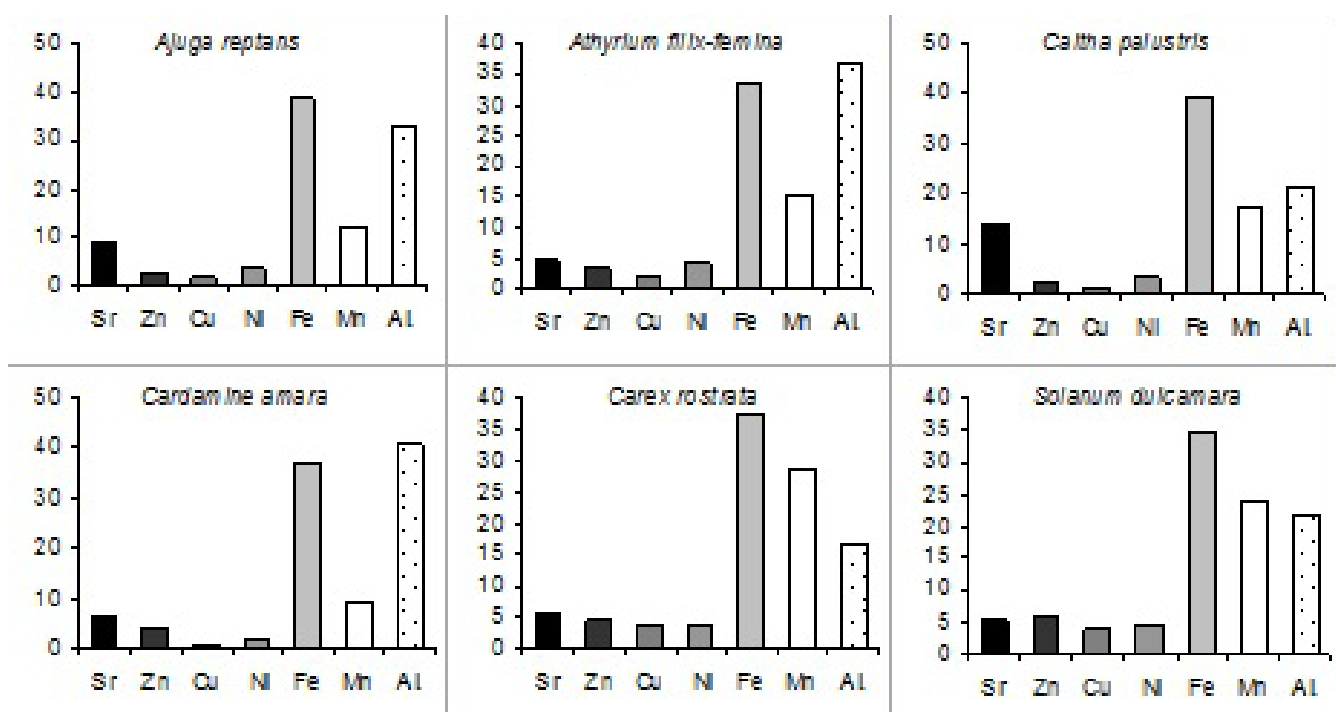

Figure 5. Percentage share of $\mathrm{Fe}, \mathrm{Zn}, \mathrm{Mn}, \mathrm{Cu}, \mathrm{Ni}, \mathrm{Sr}$ and $\mathrm{Al}$ in amount micronutrients in herbaceous plants

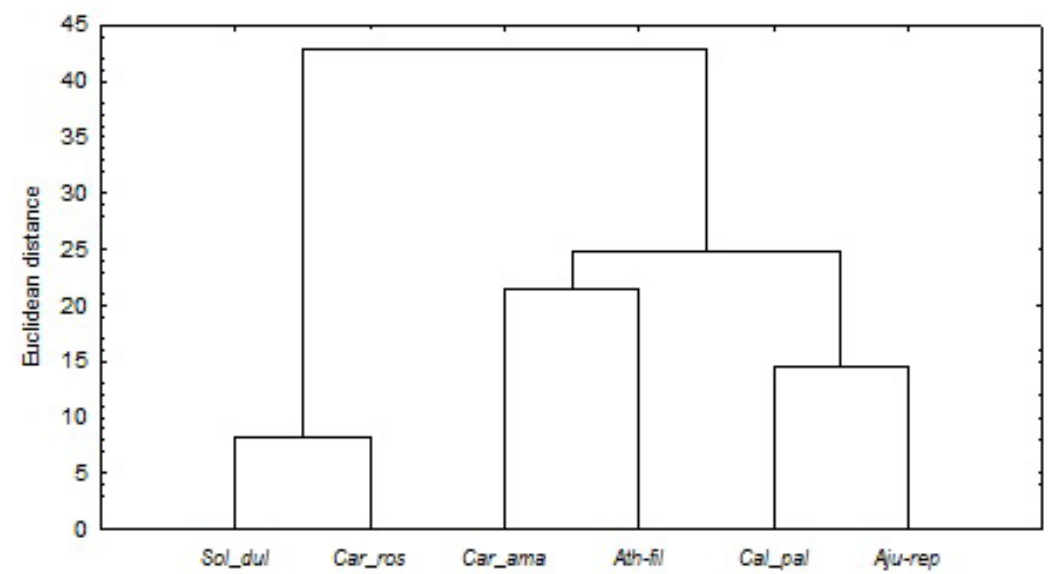

Figure 6. Dendrogram of hierarchical cluster analysis of percentage of macro- and micronutrients in shoots of herbaceous plants (Ward's method)

Cardamine amara $(\mathrm{N}, \mathrm{Cu})$ and Carex rostrata (K, Mg, Ca, Sr, Ni, Fe, Al).

The shoots of herbaceous plants accumulated from $1767.23 \mathrm{mmol}_{\mathrm{c}} \mathrm{kg}^{-1}$ to $2739.87 \mathrm{mmol}_{\mathrm{c}} \mathrm{kg}^{-1}$ of all analyzed components. Macronutrients, the share of which was over $99 \%$, were dominant in all analyzed species, and micronutrients constituted from $0.33 \%$ to $0.67 \%$. The share of nitrogen constituted from $38.8 \%$ to $56.8 \%$ of this sum, phosphorus from $2.9 \%$ to $3.9 \%$, potassium from $28.5 \%$ to $40.6 \%$, magnesium from $4.8 \%$ to $7.6 \%$, and calcium from $4.6 \%$ to $16.4 \%$. The high proportion of iron (33.7-39.5\%), manganese (9.2-28.8\%) and aluminum (16.7-40.8\%) in total of the measured microcomponents indicates their excessive absorption by plants. Among the studied herbaceous plants, Solanum dulcamara and Caltha palustris accumulated the largest amounts of nutrients. The presence of these species in river valleys strengthens the effectiveness of the protective barrier constituted by herbaceous vegetation.

\section{REFERENCES}

1. Czerwiński Z., Pracz J. 1995. Content of mineral components in the over-ground parts of herb layer plants in the Sphagno girgensohnii-Piceetum community. Pol. Ecol. Stud. 21(2), 195-205.

2. Décamps H., Pinay G., Naiman R.J., Petts G.E., McClain M.E., Hillbricht-Ilkowska A., Hanley T.A., Holmes R.M., Quinn J., Gibert J., Tabacchi A.M.P., Schiemer F., Tabacchi E., Zalewski M. 2004. Riparian zones: where biogeochemistry meets biodiversity in management practice. Pol. J. Ecol. 52, 3-18.

3. Gworek B. 2006. The toxicity of aluminium environmental challenge (reviev of literature). Environ. Prot. Nat. Res. 29, 27-38. (in Polish) 
4. Hazlett P., Broad K., Gordon A., Sibley P., Butttle J., Larmer D. 2008. The importance of catchment slope to soil water $\mathrm{N}$ and $\mathrm{C}$ concentrations in riparian zones: implications for riparian buffer width. Can. J. For. Res. 38(1), 16-30.

5. Hefting M., Clement J., Bienkowski P., Dowrick D., Guenat C., Butturini A., Topa S., Pinay G., Verhoeven J.T.A. 2005. The role of vegetation and litter in the nitrogen dynamics of riparian buffer zones in Europe. Ecol. Eng. 24, 465-482.

6. Horska-Schwarz S., Spałek K. 2008. Structure and Function of Landscape Systems: Meta-analyses, Models, Theories and Their Applications. Probl. Land. Ecol. 21, 311-318.

7. Jansson R., Hjalmar L., Eva J., Clemens A. 2007. The importance of groundwater discharge for plant species number in riparian zones. Ecology, 88, 131-139.

8. Jonczak J., Parzych A., Sobisz Z. 2014. The content and profile distribution patterns of $\mathrm{Cu}, \mathrm{Ni}$ and $\mathrm{Zn}$ in Histosols of headwater areas in the valley of Kamienna Creek (northern Poland). Balt. Coastal Zone, 18, 5-13.

9. Jonczak J., Parzych A., Sobisz Z. 2015. Decomposition of four tree species leaf litters in headwater riparian forest. Baltic Forestry, 21(1), 133-143.

10. Jonczak J., Olejniczak M., Parzych A., Sobisz Z. 2016. Dynamics, structure and chemistry of litterfall in headwater riparian forest in the area of Middle Pomerania. J. Elem., 21(2), 383-394.

11. Kabata-Pendias A., Pendias H. 1999. Biogeochemia pierwiastków śladowych. PWN, Warszawa.

12. Karlsson O.M., Richardson J.S., Kiffney P.M. 2005. Modelling organic matter dynamics in headwater streams of south-western British Columbia. Can. Ecol. Model., 183, 463-476.

13. Krzywy E. 2007. Nutrition of plants. West Pomeranian University of Technology Szczecin Press, Szczecin.

14. Kuglerova L., Jansson R., Agren A., Laudon H., Malm-Renofalt B. 2014. Groundwater discharge creates hotspots of riparian plant species richness in a boreal forest stream network. Ecology, 95, 715-725.

15. Maine M.A., Sune N., Hadad H., Sanchez G., Bonetto C. 2006. Nutrient and metal remove in a constructed wetland for wastewater treatment from a metallurgic industry. Ecol. Eng., 26, 341-347.

16. Małek S., Astel A., Krakowian K., Opałacz J. 2010. Ocena jakości wód źródlanych w rejonie Skrzycznego i Baraniej Góry. Sylwan, 154(7), 499-505.

17. Mirek Z., Piękoś-Mirkowa H., Zając A., Zając M. 2002. Flowering plants and pteridophytes of Po- land. A checklist. Biodiversity of Poland, 1, 9-442.

18. Osadowski Z. 2006. Threatened, protected and rate species of vascular plants in spring complexes in the central part of Polish Pomerania. Biodiversity Research and Conservation, 1-2, 174-180.

19. Ostrowska A., Porębska G. 2002. Chemical composition of plants, its interpretation and use in environmental protection. Instytut Ochrony Środowiska, Warszawa. (in Polish) 23. Parzych A. 2015. Accumulation of the macro- and microelements in mosses in the Słowiński National Park. Sylwan 159(4), 345-352. (in Polish)

20. Parzych A., Jonczak J., Sobisz Z. 2016. Changes of water chemistry in mid-forest headwater streams in the valley of the Kamienna (Middle Pomerania). Sylwan, 160(10), 871-880. (in Polish)

21. Parzych A., Jonczak J., Sobisz Z. 2017. Bioaccumulation of macronutrients in the herbaceous plants of mid-forest spring niches. Balt. For., 23(2), 384-393.

22. Parzych A., Jonczak J., Sobisz Z. 2018. Bioaccumulation of macro- and micronutrients in herbaceous plants of headwater areas - a case study from northern Poland. J. Elem., 23(1), 231-245.

23. Pielech R., Anioł-Kwiatkowska J., Szczęśniak E. 2015. Landscape-scale factors driving Plant species composition in mountain streamside and spring riparian forests. For. Ecol. Manag., 347, 217-227.

24. Raty M., Uusi-Kamppa J., Yli-Halla M., Rasa K., Pietola L. 2010. Phosphorus and nitrogen cycles in the vegetation of differently manager buffet zones. Nutr. Cyc. Agroecosys., 86, 121-132.

25. Samecka-Cymerman A., Kempers J. 2007. Heavy metals in aquatic macrophytes from two small rivers polluted by urban, Agricultural and Textile Industry Sewages SW Poland. Arch. Environ. Contam. Toxicol., 53, 198-206.

26. Smal H., Salomons W. 1995. Acidification and its long-term impact on metal mobility. In: Biogeodynamics of pollutants in soils and sediments. Springer-Verlag, Berlin 193-212.

27. Tufekcioglu A., Raich J., Isenhart T., Schultz R. 2003. Biomass, carbon and nitrogen dynamics of multi-species riparian buffers within an agricultural watershed in Iowa, USA. Agroforestry Systems 57, 187-198.

28. Veselkin D.V., Konoplenko M.A., Betekhtina A.A. 2014. Means for soil nutrient uptake in sedges with different ecological strategies. Rus. J. Ecol., 45, 6, 547-554.

29. Viers J.H., Fremier A.K., Hutchinson R.A., Quinn J.F., Thorne J.H., Vaghti M.G. 2012. Multiscale patterns of riparian plant diversity and implications for restoration. Res. Ecol., 20, 160-169. 